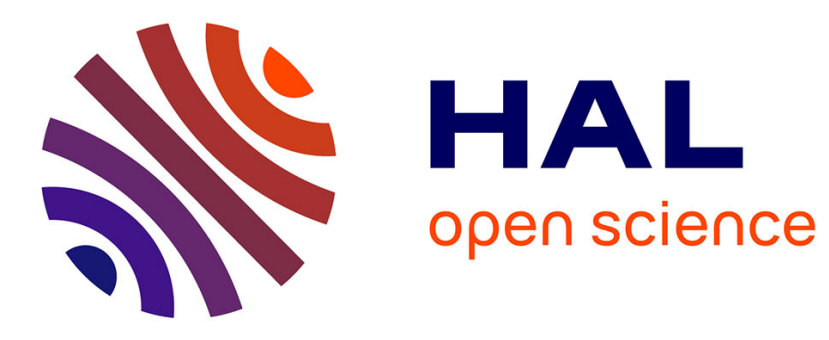

\title{
Arctic warming: non-linear impacts of sea-ice and glacier melt on seabird foraging
}

David Grémillet, Jérôme Fort, Françoise Amélineau, Elena Zakharova, Tangi Le Bot, Enric Sala, Maria V. Gavrilo

\section{- To cite this version:}

David Grémillet, Jérôme Fort, Françoise Amélineau, Elena Zakharova, Tangi Le Bot, et al.. Arctic warming: non-linear impacts of sea-ice and glacier melt on seabird foraging. Global Change Biology, 2015, 21 (3), pp.1116-1123. 10.1111/gcb.12811 . hal-01111615

\section{HAL Id: hal-01111615 \\ https://hal.science/hal-01111615}

Submitted on 18 Mar 2015

HAL is a multi-disciplinary open access archive for the deposit and dissemination of scientific research documents, whether they are published or not. The documents may come from teaching and research institutions in France or abroad, or from public or private research centers.
L'archive ouverte pluridisciplinaire HAL, est destinée au dépôt et à la diffusion de documents scientifiques de niveau recherche, publiés ou non, émanant des établissements d'enseignement et de recherche français ou étrangers, des laboratoires publics ou privés. 


\section{Arctic warming: non-linear impacts of sea-ice and glacier melt on seabird foraging}

\section{DAVID GRÉMILLET ${ }^{1,2}$, JÉRÔME FORT ${ }^{3}$, FRANÇOISE AMÉLINEAU ${ }^{1}$, ELENA}

ZAKHAROVA $^{4,5}$, TANGI LE BOT $^{1}$, ENRIC SALA $^{6,7}$ and MARIA GAVRILO ${ }^{8}$

${ }^{1}$ CEFE UMR 5175, CNRS - Université de Montpellier - Université Paul-Valéry Montpellier EPHE, 1919 route de Mende, 34293 Montpellier, France.

${ }^{2}$ FitzPatrick Institute, DST/NRF Excellence Centre at the University of Cape Town, Rondebosch 7701, South Africa.

${ }^{3}$ LIENSs UMR 7266, CNRS - Université La Rochelle, 2 rue Olympe de Gouges, 17000 La Rochelle, France.

${ }^{4}$ LEGOS UMR5566, CNRS - CNES - IRD - Université Toulouse III), 14 Avenue Edouard Belin, 31400 Toulouse, France.

${ }^{5}$ State Oceanography Institute, ul. Beringa 38, 119397 St. Petersburg, Russia.

${ }^{6}$ National Geographic Society, Washington, D. C., USA.

${ }^{7}$ Centre d'Estudis Avançats de Blanes (CEAB-CSIC), Spain.

${ }^{8}$ National Park Russian Arctic, Sovetskikh Kosmonavtov Avenue, 57, 163000 Archangelsk, Russia.

Corresponding author: David Grémillet. Email: david.gremillet@ cefe.cnrs.fr

Keywords: Arctic marine fauna, Arctic climate change, Behavioural plasticity, Cryosphere, Historical data, Little auk. 


\section{Abstract}

Arctic climate change has profound impacts on the cryosphere, notably via shrinking sea-ice cover and retreating glaciers, and it is essential to evaluate and forecast the ecological consequences of such changes. We studied zooplankton-feeding little auks (Alle alle), a key sentinel species of the Arctic, at their northernmost breeding site in Franz-Josef Land $\left(80^{\circ} \mathrm{N}\right)$, Russian Arctic. We tested the hypothesis that little auks still benefit from pristine arctic environmental conditions in this remote area. To this end we analysed remote-sensing data on sea-ice and coastal glacier dynamics collected in our study area across 1979-2013. Further, we recorded little auk foraging behaviour using miniature electronic tags attached to the birds in the summer of 2013, and compared it with similar data collected at three localities across the Atlantic Arctic. We also compared current and historical data on Franz-Josef Land little auk diet, morphometrics and chick-growth curves. Our analyses reveal that summer sea-ice retreated markedly during the last decade, leaving the Franz-Josef Land archipelago virtually sea-ice free each summer since 2005. This had a profound impact on little auk foraging, which lost their seaice associated prey. Concomitantly, large coastal glaciers retreated rapidly, releasing large volumes of melt water. Zooplankton is stunned by cold and osmotic shock at the boundary between glacier melt and coastal waters, creating new foraging hotspots for little auks. Birds therefore switched from foraging at distant ice-edge localities, to highly profitable feeding at glacier melt-water fronts within $<5 \mathrm{~km}$ of their breeding site. Through this behavioural plasticity little auks maintained their chick growth rates, but showed a $4 \%$ decrease in adult body mass. Our study demonstrates that arctic cryosphere changes may have antagonistic ecological consequences on coastal trophic flow. Such non-linear responses complicate modelling exercises of current and future polar ecosystem dynamics. 


\section{Introduction}

Global warming is twice as marked in the Arctic than at lower latitudes, and this has a rapid and profound impact on the cryosphere. For instance, the Intergovernmental Panel on Climate Change Fifth Assessment Report (IPCC, 2013) predicts a sea-ice free Arctic in summer from the 2030s, or towards the end of $21^{\text {st }}$ century, depending on scenarios. The Arctic being $70 \%$ marine, a reduction in sea-ice extent and thickness radically modifies its seascape, with major impacts on atmospheric and ocean circulation, biogeochemical cycles and ecosystem functioning (AMAP, 2012). Endemic arctic species, such as the emblematic polar bear (Ursus maritimus), are predicted to go extinct, and to be replaced by species from lower latitudes (review in Gilg et al., 2012). Yet arctic warming also leads to pronounced glacier and permafrost melt (IPCC, 2013), which strongly modify terrestrial and coastal landscapes, and associated ecological dynamics. Determining and predicting the overall impacts of cryosphere changes is therefore a key research objective (AMAP, 2012), particularly at the interface between terrestrial and marine ecosystems (Post et al., 2013). Beyond polar bears, a limited number of sea-ice associated arctic species function as sentinel species, whose ecological responses to the consequences of climate change deserve special attention. This is the case of the little auk (Alle alle), for a number of reasons: it is the most abundant seabird in the Atlantic Arctic, with over 40 million individuals, and therefore plays a major ecological role within marine ecosystems (Karnovsky \& Hunt, 2002; Karnovsky et $a l ., 2003)$. It is a specialized zooplankton consumer, and participates in a short food chain with strong responses to sea-ice presence/absence and to sea-surface temperature (Grémillet et al., 2012; Jakubas et al., 2012). It is also the smallest high arctic, diving seabird, and operates at the upper limit of its energetic capabilities, something that strongly enhances its sensitivity to environmental change (Harding et al., 2009a). Current knowledge shows that ocean warming and 
a vanishing cryosphere have a negative impact on little auks, because they preferentially feed on large, lipid-rich zooplankton (copepods) associated with cold water in the marginal ice zone (Karnovsky et al., 2010). It is therefore predicted that little auk colonies situated in warmer areas will be more impacted than those from areas that are less exposed to global warming. Yet ocean warming progresses rapidly in the North Atlantic, and it seems appropriate to test the impact of cryosphere changes on little auks at their northernmost breeding site, which is situated in FranzJosef Land (Russian State Federal Refuge), at $80^{\circ} \mathrm{N}$. This extremely remote area is often regarded as an 'arctic Eden', still shielded from the consequences of global warming, with $85 \%$ of its land mass covered by glaciers and extensive, year-round, sea-ice cover surrounding islands of the archipelago. It is home for over a million seabirds, including an estimated 500,000 little auks (Anker-Nilssen, 2000), as well as large proportions of the world populations of further endemic arctic species (e.g. polar bear, walrus Odobenus rosmarus rosmarus, ivory gull Pagophila eburnea, bowhead whale Balaena mysticetus). Previous investigations showed that little auks mainly respond to marine environmental change through marked plasticity in their foraging behaviour and diet (Grémillet et al., 2012). We therefore investigated the foraging ecology of little auks from Franz-Josef Land using miniaturised temperature-depth recorders (TDR) and dietary analyses. Adult body measurements and chick growth rates were also recorded. These fitness indicators were compared with data collected at the same study site twenty years before, and with little auk foraging behaviour from three other breeding sites across the Atlantic Arctic. Seabird data were interpreted in the context of Franz-Josef Land sea-ice and glacier dynamics, which we analyzed over the past 30 years using satellite remote-sensing. Specifically, we tested the hypothesis that little auks from Franz-Josef Land benefit from conditions of the pre-industrial 
age, with a foraging effort predicted to be lower than at other, more southern breeding sites in the Arctic.

\section{Materials and methods}

The study site was situated in Tikhaya Bay, Hooker Island, Franz-Josef Land (80²0.293'N ; $52^{\circ} 49.062^{\prime} \mathrm{E}$ ), at a little auk colony facing coastal waters and in the vicinity of the $7.2 \mathrm{~km}^{2}$ Sedov glacier (Fig. 1), during National Geographic's Pristine Seas 2013 Franz-Josef Land expedition. Little auks were studied in July-August 2013 during the chick-rearing phase, within the framework of a scientific programme approved by the board of the National Park Russian Arctic and the Ministry of Education and Science of the Russian Federation (Permit $\mathrm{N}^{\circ} 71$ issued on 03/06/2013). This phase was chosen because birds are accessible, have their highest foraging effort for self-maintenance and chick-feeding, and are therefore assumed to be most susceptible to environmental change. Four different sets of birds/nests were studied synoptically within the same colony. First, 15 birds were caught in the vicinity of their nest and equipped with TDRs (G5; CEFAS Technologies, Lowestoft, UK; $31 \mathrm{~mm}$ length, $8 \mathrm{~mm}$ diameter; $2.7 \mathrm{~g}$, corresponding to $1.7 \%$ of lightest handled little auk body mass, or DST micro-TD; StarOddi, Iceland; $25.4 \mathrm{~mm}$ length, $8.3 \mathrm{~mm}$ diameter; $3.3 \mathrm{~g}$, corresponding to $2 \%$ of the lightest handled little auk body mass), which were attached to ventral feathers using waterproof Tesa ${ }^{\circledR}$ tape. TDRs were left on the birds for 3-6 days, upon which birds were recaught and tags downloaded. TDRs recorded hydrostatic pressure and temperature every $4 \mathrm{sec}$ for the entire period (G5), or for $24 \mathrm{~h}$ starting on the day following deployment (DST microTD). Recorded temperature signals allow discrimination of periods spent at the nest, in flight, and in the water, and were therefore used to calculate the 
number of foraging trips per $24 \mathrm{~h}$, foraging trip duration and flight time per trip and per $24 \mathrm{~h}$ (for full details on analyses see Harding et al., 2009b). Pressure recordings were analyzed with MultiTrace (Jensen Software Systems, Laboe, Germany), to determine (per 24h) the number of dives, average and maximum dive depth, average and maximum dive duration, and the percent time spent underwater. Foraging parameters of little auks from Franz-Josef Land were compared with those of birds from East Greenland and from two locations on Svalbard, which were studied using the same methodology (data from Grémillet et al., 2012). This biotelemetry study was complemented by direct observations of feeding little auks, assessed on three occasions from a boat in August 2013. During these 2h sessions birds were observed from $<100 \mathrm{~m}$ on a calm sea using 12x42 binoculars, and positions recorded using a hand-held GPS. These at-sea observations were compared with similar surveys conducted in the summer of 2001. Second, breeding little auks carry undamaged zooplankton prey back to the nest in a sublingual pouch. Twenty birds carrying such food loads were also caught, and complete food loads stored in $70 \%$ ethanol. Prey identification was performed to the lowest-possible taxonomic level under a binocular microscope. Third, we marked a set of 18 little auk nests and determined chick growth (body mass to $1 \mathrm{~g}$, wing and tarsus length to $1 \mathrm{~mm}$ ) every second day throughout the chick-rearing phase (1-26 August 2013). Finally, all birds caught for TDR deployments and diet sampling were weighed to the nearest $2 \mathrm{~g}$ and measured (wing and tarsus) to the nearest $1 \mathrm{~mm}$. This sample was complemented with adult breeding birds caught synoptically within the same area for other purposes.

Diet, adult morphometrics and chick growth rates were compared with similar data collected by (Stempniewicz et al., 1996) and (Weslawski et al., 1994) within the same area in 1991-1993. We 
only had access to average body mass and body size measurements for 1991-1993, and therefore could not calculate/compare individual body condition indexes for the two periods.

Mean monthly sea-ice concentrations (percentage of ocean surface covered by sea-ice) were determined for July and August, across 1979-2013, within $100 \mathrm{~km}$ of the study colony (i.e. the maximum foraging range of breeding little auks; Anker-Nilssen, 2000; Jakubas et al., 2013) using daily EUMETSAT OSI SAF ice concentration satellite products for 1979-2009. This consisted of reprocessed SMMR and SSM/I instruments data with a spatial resolution of $12.5 \mathrm{~km}$ (Eastwood et al., 2010). AMSR-E instrument measurements with $6.25 \mathrm{~km}$ spatial resolution (Spreen et al., 2008) were used as a complement for the 2002-2013 time period, also allowing cross-checking of the two data sets across 2002-2009.

Dynamics of the Sedov glacier were studied using high resolution (60 - $15 \mathrm{~m})$ Landsat images. For the 1985-2013 period, 13 images were used, most of them acquired during July- August, the period of highest ablation, except for 1998 (April) and 2006 (September). Images were digitised, and we determined the glacier terminus position for each year. Yearly glacier progression/retreat was then calculated using 2001 as an arbitrary reference.

\section{Results}

Summer sea-ice cover (Fig. 2A) showed strong variability during 1979-2013. Until 2003 the mean monthly sea ice concentration within $100 \mathrm{~km}$ of the little auk colony varied between 40 and 70\%, and between 15-55\% in July and August, respectively. Since 2003-2004 the archipelago has been almost ice-free in August, since sea-ice tended to melt earlier each year. Only small ice- 
filled areas occurred at the north and north-east periphery of the archipelago, partly advected by winds and currents.

Coastal glaciers also retreated markedly in the study area (Fig. 2B). Since the middle of 1990s the Sedov glacier retreated progressively, and from the year of its maximal surface area in 1994 to 2012 it has been shrinking by $0.64 \mathrm{~km}^{2}$. This corresponds to a 9\% reduction of its 1994 surface $\left(7.2 \mathrm{~km}^{2} ; 0.50 \%\right.$ decrease per year). In order to verify that these observations are robust, we compared this dynamic with that of the neighbouring Yuria glacier (Fig. 1). For this glacier the total 1985-2012 retreat of the terminus position was even higher, with a $18 \%$ decrease of its initial $12.5 \mathrm{~km}^{2}$ area $(0.66 \%$ per year), and a major decline between $2002-2012$.

All 15 TDRs deployed were recovered. One data file was corrupted and we therefore present data for 14 birds (S1). Little auks foraged extensively, performing an average of 6 feeding trips and 361 dives per day. Dives were usually short (36 sec) and shallow $(6.2 \mathrm{~m})$, but birds occasionally dived $>1 \mathrm{~min}$ to $>20 \mathrm{~m}$ depth. Diving effort was comparable to that of little auks diving in three other regions of the Arctic (Fig. 3A\&B, see also S2). However, and most surprisingly, flight time per foraging trip was at least one order of magnitude lower in little auks from Franz-Josef Land than in birds from three other arctic regions (Fig. 3C\&D). Such short flight times (usually $<4$ min) between breeding colony and feeding area indicated that birds did not feed offshore, but extremely close to the colony. We confirmed this through direct at-sea observations of little auks: birds were seen between foraging dives, positioned along the front separating glacier melt from coastal waters (Fig. 1 and S3). Birds were only present at this front, on the sea side where water was much clearer than in glacial melt water. Conversely, at-sea surveys conducted in the summer 
of 2001 showed that little auks foraged in the marginal ice zone, northwest of the Franz-Josef archipelago (S4).

Little auk diet was largely dominated by copepods, which were present in all samples and represented $95.7 \%$ of all prey items (Tab. 1). These copepods were mainly Calanus glacialis and C. hyperboreus, two cold-water associated species. This diet differed markedly from data collected in 1991-1993 at the same study site (Weslawski et al., 1994). Those showed that at that time little auks not only fed on copepods, but also to $13 \%$ on Apherusa glacialis, a sea-ice associated amphipod which was present in the food of $49 \%$ of all little auks sampled in 19911993. This particular prey was absent from all but one of our 2013 samples (i.e. a proportion of $0.5 \%$ of all prey and $5 \%$ occurrence, see also S5). Growth curves of little auk chicks measured in August 1992 (Stempniewicz et al., 1996) and in August 2013 (our study) were identical (Fig. 4). Adult body measurements ( $n=57$ in 1992 and $n=108$ in 2013) showed that birds were 4\% lighter in $2013(194.1 \pm 11.9 \mathrm{~g})$ than in $1992(202.3 \pm 12.5 \mathrm{~g} ; \mathrm{t}=4.07, \mathrm{p}<0.001)$, but that other measurements were not significantly different between the two periods (Wing length: 133.3 \pm $3.7 \mathrm{~mm}$ in 1992 and $133.0 \pm 4.0 \mathrm{~mm}$ in 2013. Tarsus length: $23.1 \pm 0.8 \mathrm{~mm}$ in 1992 and $23.5 \pm$ $1.0 \mathrm{~mm}$ in 2013).

\section{Discussion}

Our results allow two important conclusions: (1) the consequences of global warming are strongly modifying coastal marine ecosystems even in Franz-Josef Land, an extremely remote, high-Arctic locality. (2) Disappearance of summer sea-ice from the archipelago and pronounced coastal glacier melt have antagonistic effects on little auk foraging behaviour, leading to a non- 
linear response to climate change in this endemic, ecologically highly important arctic species (Fig. 5). Our work is strongly multidisciplinary, and features the first comprehensive investigation of little auk foraging ecology in relation to sea-ice and coastal glacier melt.

Studying the overall impacts of cryosphere changes on arctic biodiversity has been identified as a major scientific challenge by the Arctic Council and its working groups (e.g. AMAP, 2012), as well as by international research initiatives such as the Belmont Forum. Specifically, there is currently a lack of studies that integrate terrestrial and marine processes and investigate the impacts of arctic climate change in coastal areas (Post et al., 2013). Further, the IPCC (IPCC, 2013) and the Belmont Forum have stressed the importance of identifying non-linear responses of organisms and populations to global change. Our research fits tightly to these objectives, and builds upon existing, yet limited, work on sea-ice associated marine predators in the context of climate change (Gaston et al., 2005; Eamer et al., 2013). In a global perspective, little auks appear as the arctic ecological equivalent to Adélie penguins (Pygoscelis adeliae). For this species, extensive Antarctic research has demonstrated the importance of the marginal ice zone for efficient foraging on krill (Euphausia $s p$.) and fish, whereby birds require specific, intermediate sea-ice concentrations for an optimal provisioning efficiency (Emmerson \& Southwell, 2008; Ballard et al., 2012). Interestingly, recent investigations also demonstrated nonlinear responses of Adélie penguins to climate change, whereby their plastic phenotypic response to variable sea-ice concentration was perturbed by extreme climatic events (Lescroël et al., 2014). Further, our results are also in line with recent studies and syntheses from other arctic regions, which stressed the importance of glacier outflow into coastal ecosystems, and the ecological consequences of a climate-induced increase of such outflow. In Alaska, for instance, researchers demonstrated that enhanced glacier discharge generate trophic cascades in arctic fjord 
ecosystems (Arimitsu et al., 2012), whereby melt water fronts attract pelagic fish suitable for seabird foraging (Renner et al., 2012). For the Svalbard region, Lydersen and colleagues (Lydersen et al., 2014) identified similar dynamics as those demonstrated by our study, with seaice rapidly disappearing as a resting and foraging habitat for a series of seabirds and marine mammals, and glacier melt water enhancing primary and secondary productivity in coastal ecosystems, to the benefit of some members of the marine predator guild. Their important conclusion was that this effect might only be temporary, as some of the coastal glaciers might retreat from the coastline if arctic warming persists. The little auk population of Franz-Josef Land is therefore predicted to benefit from profitable foraging conditions close to shore as long as coastal glaciers are melting. According to glacier melt recorded over the last decades $(0.5-0.6 \%$ of total surface per year, see results), and assuming a linear process, a complete melt of the Sedov glacier would be completed in approximately 180 years. However, the glacier might have retreated sufficiently far inland to stop influencing coastal ecological dynamics decades before.

Karnovsky and colleagues (2010) predicted that $40 \%$ of all major little auk colonies would disappear from the Atlantic Arctic by the end of the $21^{\text {st }}$ century. Their prediction, which was based on zooplankton thermal niche modelling under the influence of increasing sea-surface temperature, now has to be revisited in the context of arctic coastal glacier melt and little auk behavioural plasticity. Little auks were so far considered as an archetype of endemic, specialized arctic predator bound to disappear from a warming Arctic. Actually they show surprising flexibility, allowing them to maintain fitness levels (Grémillet et al., 2012; this study). Work conducted at little auk breeding sites across the Arctic clearly demonstrates the importance of cold water and associated large, lipid -rich copepods for their profitable foraging (Frandsen et al., 2014; Kwasniewski et al., 2010; Karnovsky et al., 2011), as well as their close association with 
the marginal ice zone (Jakubas et al., 2013). However, our study demonstrates that glacier melt water can also generate optimal foraging conditions for this species, as a refuge coastal habitat in the absence of sea-ice. Higher variability in diving effort for little auks from Franz-Josef Land compared to other localities (Fig.3A\&B) nonetheless suggests lower predictability in food availability at glacier melt-water fronts. Further, it is unclear to us why little auks make such profitable use of this new foraging habitat in Franz-Josef Land, and not at other arctic localities. This may be due to the geography of the archipelago, with a very high number of small islands covered by glaciers. Franz-Josef Land therefore has a many more glacier fronts exposed to coastal waters than Svalbard, for instance. This presumption calls for further studies assessing the importance of coastal glacier frontal zones to foraging little auks at the meta-population level.

There is currently a huge demand for predicting the fate of arctic biodiversity exposed to ongoing climate change. At the species level, this is achieved by building habitat models linking distribution ranges with a suite of abiotic and biotic environmental variables (Elith \& Leathwick, 2009). This environmental envelope is then extrapolated to generate predicted future distributions (e.g. Péron et al., 2012; Beaugrand et al., 2014). In this context, and as clearly demonstrated by our study, it is essential to identify and implement key environmental drivers. Ignoring some of these factors, and neglecting non-linear, plastic behavioural responses of the species involved (Fig. 5) may lead to erroneous predictions (Barnagaud et al., 2012; La Sorte \& Jetz, 2012; Schurr et al., 2012). 


\section{Acknowlegdements}

This study was conducted in the specially protected area of the Franz-Josef Land State Federal Refuge, within the framework of the joint international expedition of National Park Russian Arctic and a National Geographic 'Pristine Seas Expedition FJL 2013'. The expedition was funded by National Geographic, Blancpain, and Davidoff Cool Water. DG and JF are funded by CNRS and the European Union (Marie Curie CIG; Project 631203 to JF), and by the French Polar Institute (ADACLIM program $\mathrm{N}^{\circ} 388$ ). We are grateful to the Russian Geographical Society for its support, and to the Russian Arctic National Park for research permits. We warmly thanks the international 'Pristine Seas' team and all persons present on board Polaris during the expedition. We are also immensely grateful to all Russian colleagues present at Tikhaya Bay station in August 2013 for their hospitality, in particular to our bodyguard Vladimir Kretov for endless patience during fieldwork. We thank Craig R. White for advice on allometry, Delphine Bonnet and Rumsais Blatrix for their assistance throughout the zooplankton analyses. 


\section{References}

AMAP (2012) Arctic Climate Issues 2011: Changes in Arctic Snow, Water, Ice and Permafrost. SWIPA 2011 Overview Report. Arctic Monitoring and Assessment Programme (AMAP), Oslo. $x i+97 p p$.

Anker-Nilssen T (2000) The status of marine birds breeding in the Barents Sea region. Norsk Polarinstitutt Rapport $\mathrm{N}^{\circ} 113$. Pp. 131-136.

Arimitsu ML, Piatt JF, Madison EN, Conaway JS, Hillgruber N (2012) Oceanographic gradients and seabird prey community dynamics in glacial fjords. Fisheries Oceanography, 21, 148169.

Ballard G, Jongsomjit D, Veloz SD, Ainley DG (2012) Coexistence of mesopredators in an intact polar ocean ecosystem: The basis for defining a Ross Sea marine protected area. Biological Conservation, 156, 72-82.

Barnagaud J-Y, Devictor V, Jiguet F, Barbet-Massin M, Le Viol I, Archaux F (2012) Relating Habitat and Climatic Niches in Birds. Plos One, 7, e32819.

Beaugrand G, Goberville E, Luczak C, Kirby RR (2014) Marine biological shifts and climate. Proceedings of the Royal Society B-Biological Sciences, 281, UNSP 20133350.

Eamer J, Donaldson G, Gaston T et al. (2013) Life linked to ice. A guide to sea-ice associated biodiversity in this time of rapid change. Conservation of Arctic Flora and Fauna (CAFF). Akureyri, Iceland. Conservation of Arctic Flora and Fauna (CAFF), Akureyri, Iceland.

Eastwood S, Larsen KR, Lavergne T, Nielsen E, Tonboe R (2010) Global Sea Ice Concentration Reprocessing - Product User Manual, EUMETSAT OSI SAF report. SAF/OSI/CDOP/met.no/TEC/MA/138, v1.1. 
Elith J, Leathwick JR (2009) Species Distribution Models: Ecological Explanation and Prediction Across Space and Time. Annual Review of Ecology Evolution and Systematics, 40, pp. $677-697$.

Emmerson L, Southwell C (2008) Sea ice cover and its influence on Adelie Penguin reproductive performance. Ecology, 89, 2096-2102.

Frandsen MS, Fort J, Rigét FF, Galatius A, Mosbech A (2014) Composition of chick meals from one of the main little auk (Alle alle) breeding colonies in Northwest Greenland. Polar Biology, 37, 1055-1060.

Gaston AJ, Gilchrist HG, Hipfner J (2005) Climate change, ice conditions and reproduction in an Arctic nesting marine bird: Brunnich's guillemot (Uria lomvia L.). Journal of Animal Ecology, 74, 832-841.

Gilg O, Kovacs KM, Aars J et al. (2012) Climate change and the ecology and evolution of Arctic vertebrates. Annals of the New York Academy of Sciences, 1249, 166-190.

Grémillet D, Welcker J, Karnovsky NJ et al. (2012) Little auks buffer the impact of current Arctic climate change. Marine Ecology Progress Series, 454, 197-206.

Harding AMA, Kitaysky AS, Hall ME et al. (2009a) Flexibility in the parental effort of an Arctic-breeding seabird. Functional Ecology, 23, 348-358.

Harding AMA, Egevang C, Walkusz W, Merkel F, Blanc S, Grémillet D (2009b) Estimating prey capture rates of a planktivorous seabird, the little auk (Alle alle), using diet, diving behaviour, and energy consumption. Polar Biology, 32, 785-796.

IPCC (2013) Climate Change 2013: The Physical Science Basis. Contribution of Working Group I to the Fifth Assessment Report of the Intergovernmental Panel on Climate Change. [Stocker, T.F., D. Qin, G.-K. Plattner, M. Tignor, S.K. Allen, J. Boschung, A. Nauels, Y. 
Xia, V. Bex and P.M. Midgley (eds.)] Cambridge University Press, Cambridge, United Kingdom and New York, NY, USA, 1535 pp.

Jakubas D, Iliszko L, Wojczulanis-Jakubas K, Stempniewicz L (2012) Foraging by little auks in the distant marginal sea ice zone during the chick-rearing period. Polar Biology, 35, 73-81. Jakubas D, Trudnowska E, Wojczulanis-Jakubas K et al. (2013) Foraging closer to the colony leads to faster growth in little auks. Marine Ecology Progress Series, 489, 263-278.

Karnovsky NJ, Hunt GL (2002) Estimation of carbon flux to dovekies (Alle alle) in the North Water. Deep-Sea Research Part Ii-Topical Studies in Oceanography, 49, 5117-5130.

Karnovsky NJ, Kwasniewski S, Weslawski JM, Walkusz W, Beszczynska-Moller A (2003) Foraging behavior of little auks in a heterogeneous environment. Marine Ecology Progress Series, 253, 289-303.

Karnovsky N, Harding A, Walkusz W et al. (2010) Foraging distribution of little auks (Alle alle) across the Greenland Sea: implications of present and future Arctic climate change. Marine Ecology Progress Series, 415, 283-293.

Karnovsky NJ, Brown ZW, Welcker J et al. (2011) Inter-colony comparison of diving behavior of an Arctic top predator: implications for warming in the Greenland Sea. Marine Ecology Progress Series, 440, 229-240.

Kwasniewski S, Gluchowska M, Jakubas D et al. (2010) The impact of different hydrographic conditions and zooplankton communities on provisioning Little Auks along the West coast of Spitsbergen. Progress in Oceanography, 87, 72-82.

Lescroël A, Ballard G, Grémillet D, Authier M, Ainley DG (2014) Antarctic Climate Change: Extreme Events Disrupt Plastic Phenotypic Response in Adelie Penguins. Plos One, 9, e85291. 
Lydersen C, Assmy P, Falk-Petersen S et al. (2014) The importance of tidewater glaciers for marine mammals and seabirds in Svalbard, Norway. Journal of Marine Systems, 129, 452471.

Péron C, Weimerskirch H, Bost C-A (2012) Projected poleward shift of king penguins' (Aptenodytes patagonicus) foraging range at the Crozet Islands, southern Indian Ocean. Proceedings of the Royal Society B: Biological Sciences, 279, 2515-2523.

Post E, Bhatt US, Bitz CM et al. (2013) Ecological Consequences of Sea-Ice Decline. Science, 341, 519-524.

Renner M, Arimitsu ML, Piatt JF (2012) Structure of marine predator and prey communities along environmental gradients in a glaciated fjord. Canadian Journal of Fisheries and Aquatic Sciences 69, 2029-2045.

Schurr FM, Pagel J, Cabral JS et al. (2012) How to understand species' niches and range dynamics: a demographic research agenda for biogeography. Journal of Biogeography, 39, 2146-2162.

La Sorte FA, Jetz W (2012) Tracking of climatic niche boundaries under recent climate change. Journal of Animal Ecology, 81, 914-925.

Spreen G, Kaleschke L, Heygster G (2008) Sea ice remote sensing using AMSR-E 89-GHz channels. Journal of Geophysical Research-Oceans, 113, C02S03.

Stempniewicz L, Skakuj M, Iliszko L (1996) The little auk Alle alle polaris of Franz Josef Land: A comparison with Svalbard Alle alle populations. Polar Research, 15, 1-10.

Weslawski JM, Stempniewicz L, Galaktionov K (1994) Summer diet of seabirds from the Frans Josef Land archipelago, Russian Arctic. Polar Research, 13, 173-181. 
Table 1. Comparison of little auk diet on Hooker Island, Franz-Joseph Land, in 2013 (n = 20, our study) and in 1991-1993 ( $\mathrm{n}=47$, (Weslawski et al., 1994)). Note the importance of Calanus copepods (bold) and quasi disappearance of ice-associated Apherusa glacialis and Gammarus wilkitzkii (bold) in 2013.

\begin{tabular}{lllll}
\hline & \multicolumn{1}{c}{$\begin{array}{c}\mathbf{1 9 9 1 - 1 9 9 3} \\
\text { Relative } \\
\text { abundance (\%) }\end{array}$} & $\begin{array}{l}\text { Occurrence } \\
\text { frequency (\%) }\end{array}$ & $\begin{array}{l}\text { Relative } \\
\text { abundance (\%) }\end{array}$ & $\begin{array}{l}\mathbf{2 0 1 3} \\
\text { Occurrence } \\
\text { frequency (\%) }\end{array}$ \\
\hline Calanus spp & $\mathbf{8 4 , 4 4}$ & $\mathbf{4 9 , 0 0}$ & $\mathbf{9 5 , 7 3}$ & $\mathbf{1 0 0 , 0 0}$ \\
Paraeuchaeta.spp & 0,00 & 0,00 & 0,30 & 35,00 \\
Metrida longa & 0,00 & 0,00 & 0,42 & 20,00 \\
Apherusa glacialis & $\mathbf{1 3 , 1 5}$ & $\mathbf{4 9 , 0 0}$ & $\mathbf{0 , 5 1}$ & $\mathbf{5 , 0 0}$ \\
Onisimus.spp & 0,10 & 6,00 & 0,03 & 5,00 \\
Themisto.spp & 1,07 & 64,00 & 1,15 & 60,00 \\
Decapods larvae & 0,10 & 9,00 & 0,73 & 50,00 \\
Gammarus wilkitzkii & $\mathbf{0 , 2 2}$ & $\mathbf{1 5 , 0 0}$ & $\mathbf{0 , 0 0}$ & $\mathbf{0 , 0 0}$ \\
Thysanoessa spp & 0,52 & 6,00 & 0,00 & 0,00 \\
Mysis oculata & 0,12 & 11,00 & 0,00 & 0,00 \\
Fishs & 0,12 & 9,00 & 0,36 & 40,00 \\
Ostracoda spp & 0,12 & 2,00 & 0,00 & 0,00 \\
Acanthostepheia spp & 0,02 & 2,00 & 0,00 & 0,00 \\
Chaetognats & 0,00 & 0,00 & 0,01 & 5,00 \\
Undetermined & 0,00 & 0,00 & 0,77 & 40,00 \\
\hline
\end{tabular}




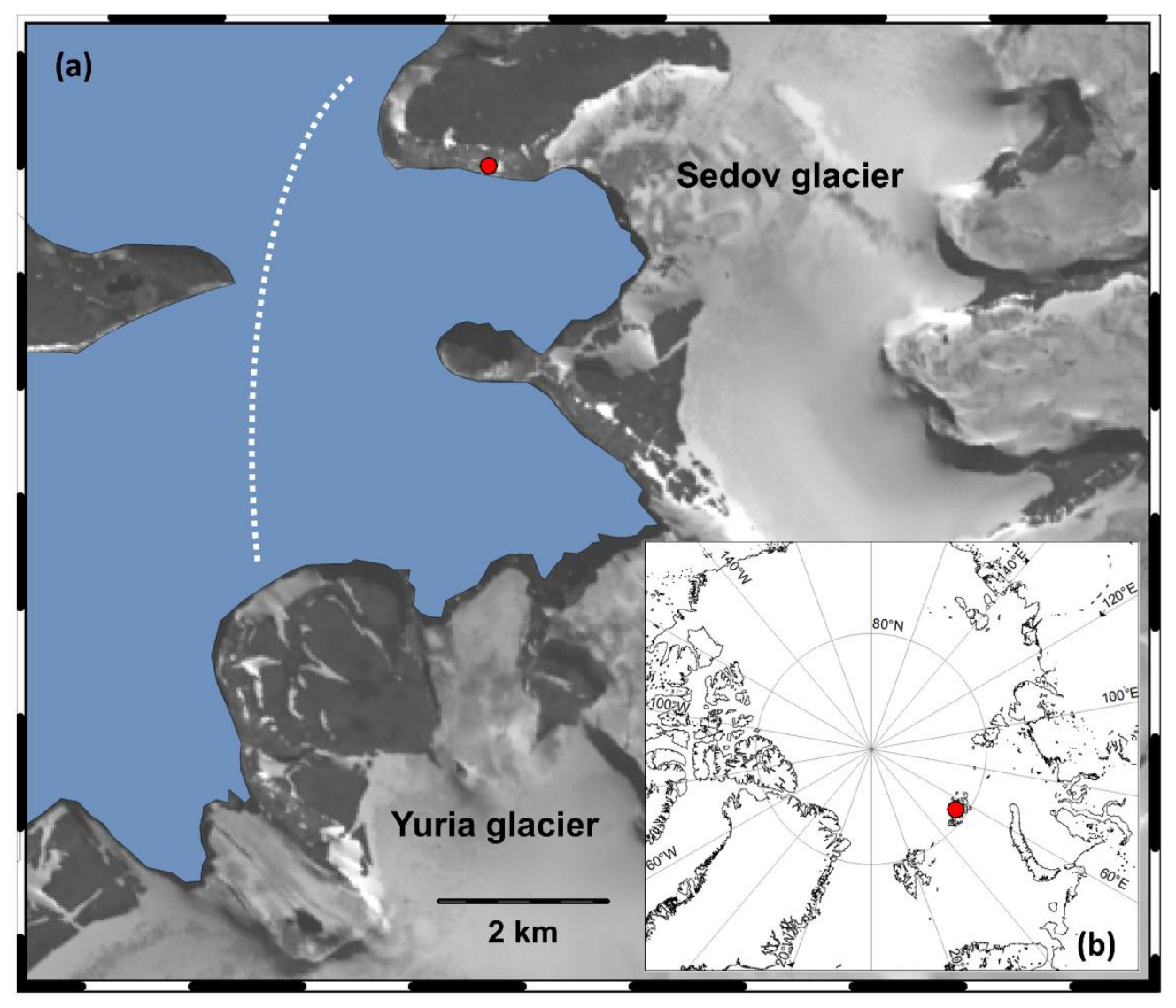

Figure 1. (a) Study area on Hooker Island, Franz-Josef Land (from a 2006 Landsat image), showing the study colony (red dot) facing Tikhaya Bay, local glaciers (white), coastal waters (blue), and approximate position of the coastal front between coastal water and glacier melt water in August 2013 (dotted line, see S1). (b) Situation of Franz-Josef Land (red dot) in the high Arctic. 

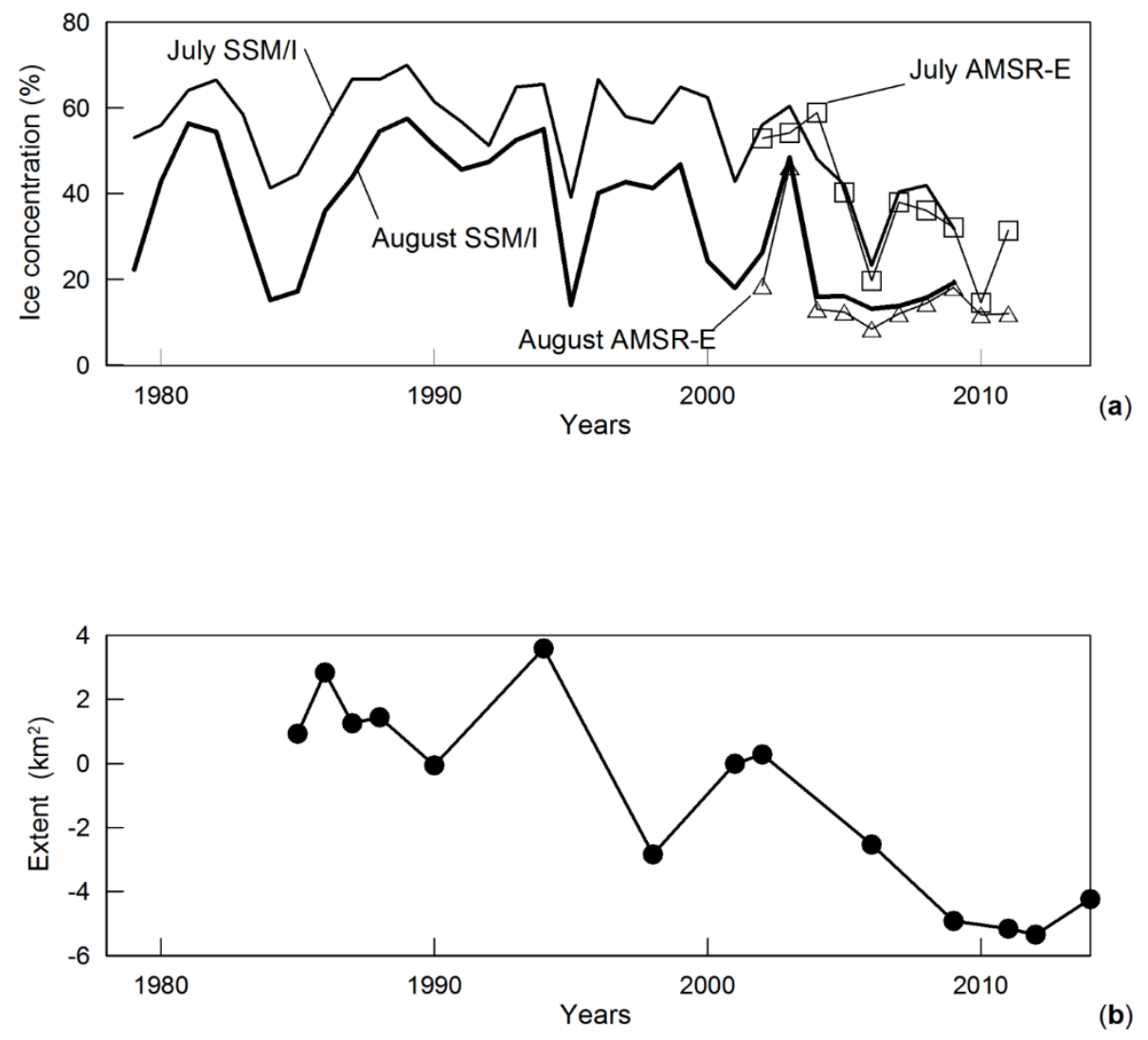

Figure 2. (a) Interannual variability of August and July mean sea ice concentration within 100 $\mathrm{km}$ of the little auk colony of Tikhaya Bay, from the two satellite products (SSMR+SSM/I across 1979-2009 and AMSR-E across 2002-2013). (b) Variation of the extent of the Sedov glacier $\left(\mathrm{Km}^{2}\right)$ relative to its 2001 extent. 

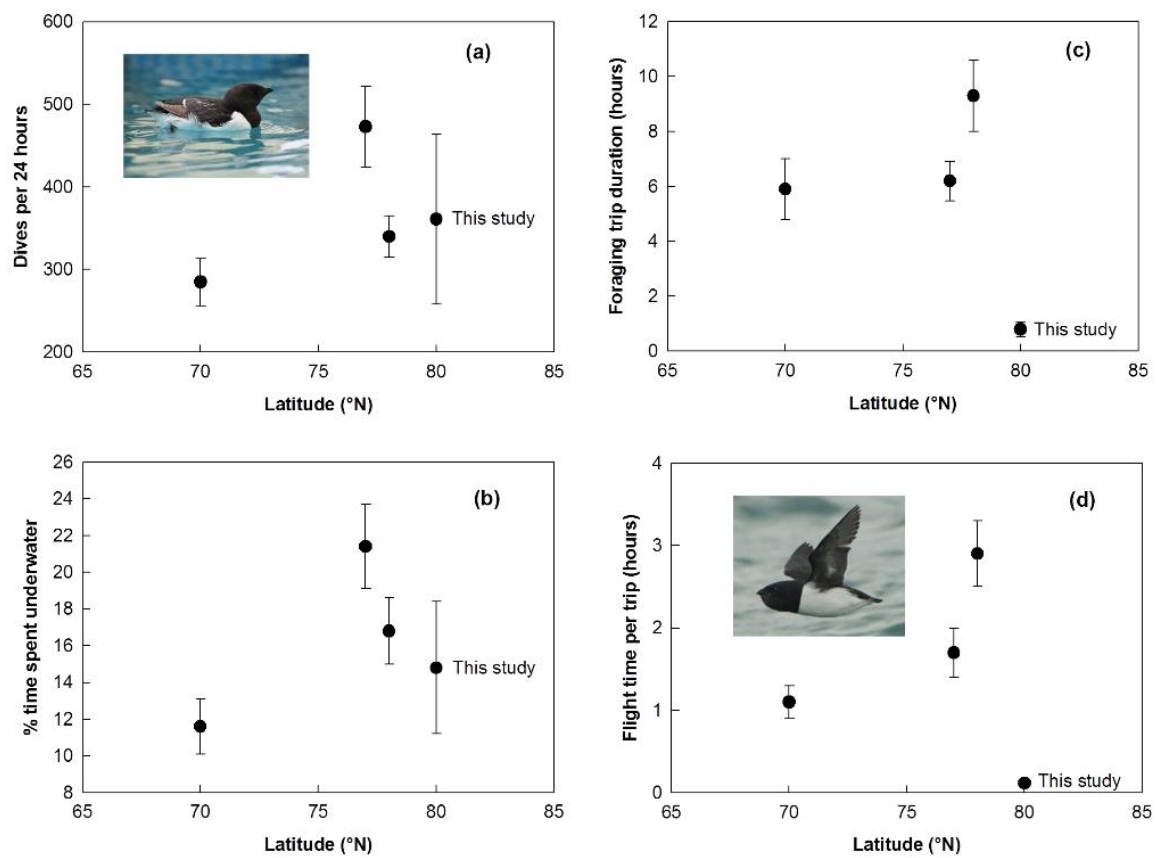

Figure 3. Foraging characteristics $($ mean $\pm S D)$ of little auks from four breeding colonies in the North Atlantic, according to the latitude of the different sites: $70^{\circ} \mathrm{N}$ : Kap Hoegh, East Greenland (6 birds); $77^{\circ} \mathrm{N}$ : Hornsund, Southern Spitsbergen (11 birds); $78^{\circ} \mathrm{N}$ : Kongsforden, Northern Spitsbergen (7 birds); $80^{\circ} \mathrm{N}$ : Hooker Island, Franz-Josef Land (14 birds). Data from Franz-Josef Land are from this study, others from (Grémillet et al., 2012). Picture credits: Manfred Enstipp \& David Grémillet. 


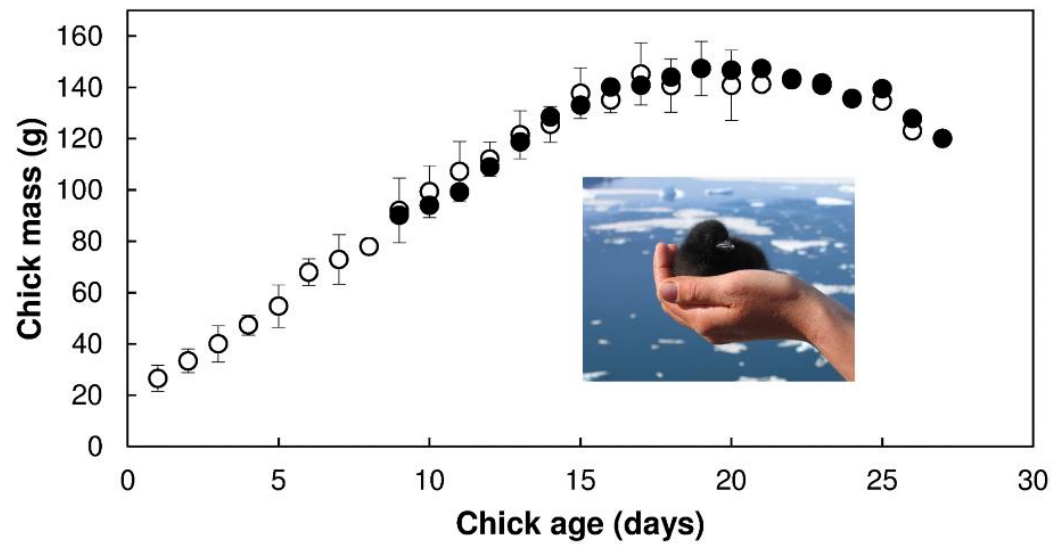

Figure 4: Little auk chick growth curves from Franz-Josef Land measured in 1992 (black circles; Stempniewicz et al., 1996) and in 2013 (open circles, $n=18$ chicks; this study). Error bars show standard deviations of the mean. Absence of error bars after 20 days is due to sample sizes of one for each age group. Picture credit: Ann Harding. 

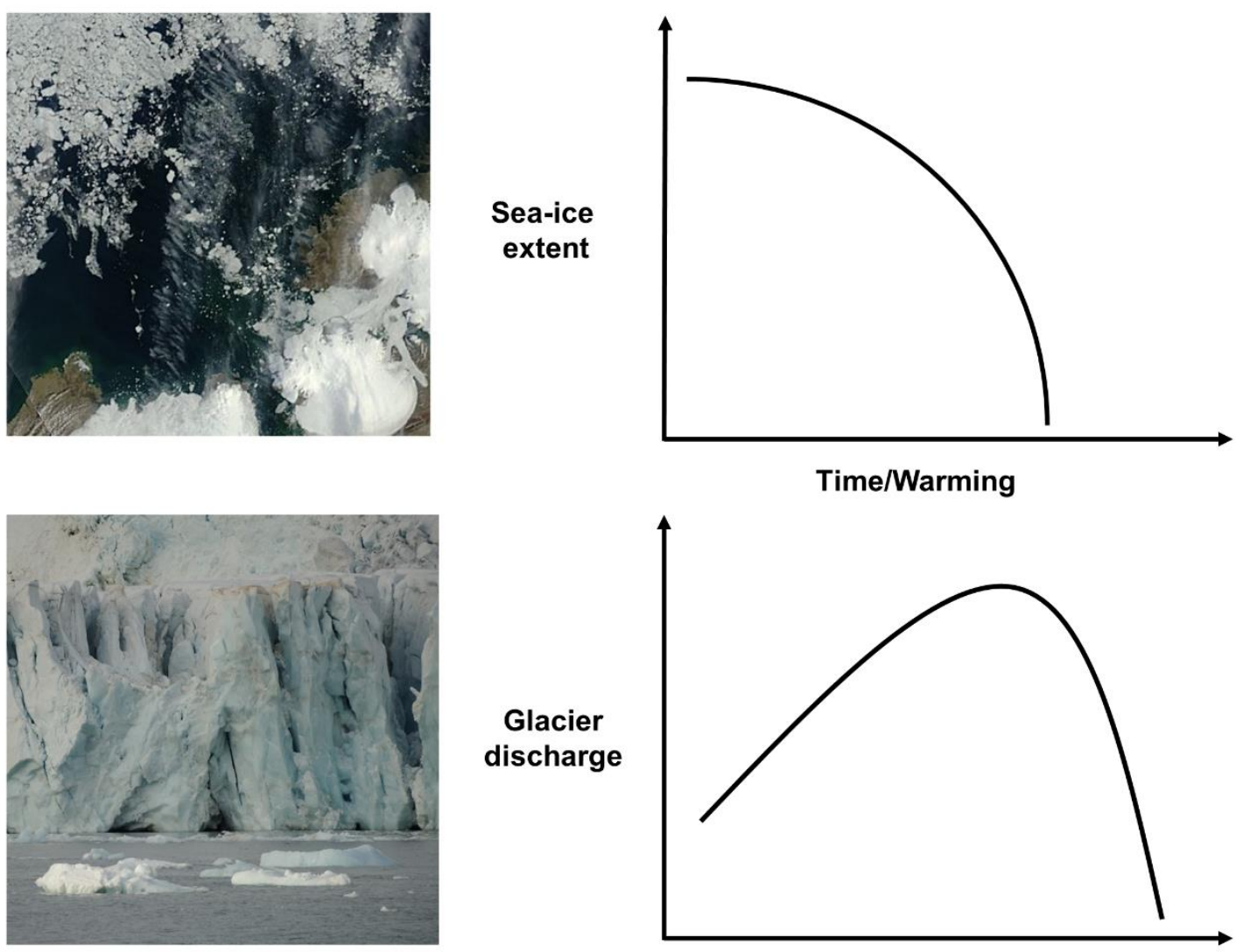

Time/Warming
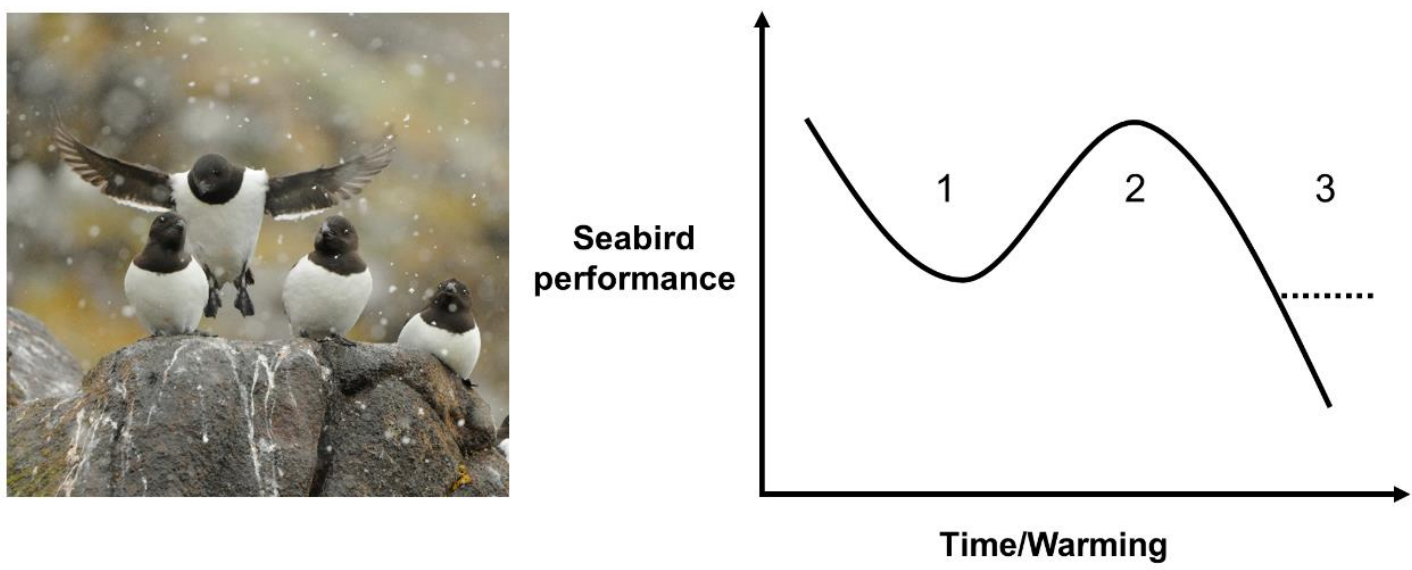

Figure 5: Hypothetical non-linear impacts of sea-ice disappearance and coastal glacier melt onto the performance (foraging profitability and fitness) of ice-associated seabirds. Slopes are 
arbitrary. Note that sea-ice disappearance is initially predicted to have a negative impact on seabirds (1), until glacier discharge is sufficiently strong to create a new coastal foraging habitat (2; current situation in Franz-Josef Land). Reduction of glacier discharge in the absence of seaice is then predicted to further diminish seabird performance (3), but foraging plasticity might allow birds to switch to another feeding mode and stabilize/improve their performance (dotted line). Picture credits: NASA \& David Grémillet. 